\title{
Research Article: Economic performance of pigeonpea in Raigarh district of Chhattisgarh state
}

\section{ANIL DIVYA, HULAS PATHAK AND CHANDRESH KUMAR DHURWEY}

Article Chronicle:

Received :

19.07.2017;

Accepted :

03.08.2017

KEY WoRds:

Pigeonpea, Cost and

Return, Marketing

Pattern, Constraints

Author for correspondence :

\section{ANIL DIVYA}

Department of

Agricultural Economics, Indira Gandhi

Agricultural University,

RAIPUR (C.G.) INDIA

Email : anildivya@

live.com

See end of the article for

authors' affiliations
SUMMARY : The present study was conducted in the Raigarh district of Chhattisgarh. Hundred farmers were selected randomly from five blocks namely Dharamjaigarh, Lailunga, Pusour, Baramkela and Sarangarh. The primary data were collected for the year 2013-14. The major findings of this study revealed that the average size of holding of the sample households was 3.19. Cost of production per quintal of pigeonpea showed decreasing trend with the increase in farm size, whereas cost of cultivation increased with the increase in farm size. Per hectare pigeonpea production and input-output ratio increased with the increase in farm size. The two marketing channels were identified for the marketing of pigeonpea: Channel-I: Producer - Village merchant. Channels-II: Producer - consumer. The major constraints pertaining to cultivation of pigeonpea were low adoption of recommended package practices of crops, followed by lack of technical knowledge and lack of financing. Constraints of marketing of pigeonpea were lack of regulated or co-operative market followed by lack of market intelligence and lack of storage facility. Study suggested establishing the regulated or co-operative market in Raigarh district and imparting the technical knowledge and extension support so that farmers can adopt improved technologies with assured irrigation facilities. It is essential to adopt the production system approach by linking the production technology, credit and marketing of pigeonpea, the study suggested.

How to cite this article : Divya, Anil, Pathak, Hulas and Dhurwey, Chandresh Kumar (2017). Economic performance of pigeonpea in Raigarh district of Chhattisgarh state. Agric. Update, 12(TECHSEAR-7) : 18421847; DOI: 10.15740/HAS/AU/12.TECHSEAR(7)2017/1842-1847. 